\title{
Persepsi Konsumen Terhadap Peraturan Gubernur Bali No.97 Tahun 2018 Tentang Pembatasan Timbulan Sampah Plastik Sekali Pakai di Kecamatan Mendoyo, Jembrana, Bali
}

\author{
Ni Komang Mei Triyasmita*1, Luh Indrayani² \\ 1,2 Program Studi Pendidikan Ekonomi \\ Universitas Pendidikan Ganesha \\ Singaraja, Indonesia
}

e-mail: meitriyasmita@gmail.com*1, luh indrayani@undiksha.ac.id

\section{Riwayat Artikel Tanggal diajukan: 9 April 2021 \\ Tanggal diterima : 23 Oktober 2021 \\ Tanggal dipublikasikan: 15 Desember 2021}

Pengutipan: Triyasmita, N. K. M. \& Indrayani. L. (2021). Persepsi Konsumen

Terhadap

Peraturan Gubernur Bal

No.97 Tahun 2018 Tentang Pembatasan

Timbulan Sampah Plastik

Sekali Pakai di Kecamatan

Mendoyo,

Kabupaten Jembrana, Bali.

Jurnal Pendidikan

Ekonomi

Undiksha, 13

(2),293-299

http://dx.doi.org/1 0.23887/iipe.v13i 2.33650

\begin{abstract}
Abstrak
Tujuan dari penelitian ini yaitu untuk mengetahui persepsi konsumen terhadap Peraturan Gubernur Bali No.97 Tahun 2018 tentang pembatasan timbulan sampah plastik sekali pakai, jenis penelitian ini adalah jenis penelitian deskriptif untuk mendeskripsikan mengenai persepsi konsumen terhadap Peraturan Gubernur Bali No.97 Tahun 2018 tentang pembatasan timbulan sampah plastik sekali pakai. Populasi dalam penelitian ini adalah seluruh konsumen yang ada di Kecamatan Mendoyo, Kabupaten Jembrana, Bali, dengan tehnik pengambilan sampel yaitu menggunakan tehnik insidental sampling dan diperoleh sampel sebanyak 330 orang. Hasil penelitian ini dilihat dari dimensi kebutuhan memperoleh skor sebesar 4.144 yang berada pada rentang skor 3.366 - 4.158 sehingga dikategorikan sangat setuju, dimensi harapan memperoleh skor sebesar 16.603 yang berada pada rentang skor 14.586 - 18.018 sehingga dikategorikan sangat setuju dan untuk dimensi pengalaman memperoleh skor 6.625 yang berada didalam rentang skor 5.147 - 6.731 yang artinya berada dalam kategori setuju.
\end{abstract}

Kata Kunci: Persepsi; Konsumen; Peraturan Gubernur Bali No.97 Tahun 2018

\section{Abstract}

The purpose of this study is to identify consumer perception towards Bali Governor Regulation Number 97 of 2018 on restrictions of disposable plastic waste. This research used a descriptive type research to analyze consumer perception towards Bali Governor Regulation Number 97 of 2018 on restrictions of disposable plastic waste. The population in this study include all consumers in Mendoyo Subdistrict, Jembrana Regency, Bali. This research used incidental sampling techniques which and obtained samples as many as 330 people. The results of this study were categorized in several dimensions namely dimension of need which obtained a score of 4,144 in the score range of 3,366 - 4,158 thus it is categorized as highly favorable, dimension of expectation obtained a score of 16,603 in the score range of 14,586 18,018 thus it is categorized as highly favorable, and dimension of experience obtained a score of 6,625 in the score range of 5,147 - 6,731 thus it is categorized as favorable.

Keywords : Perception; Consumer; Bali Governor Regulation Number 97 of 2018 


\section{PENDAHULUAN}

Pulau Bali merupakan salah satu pulau yang menjadi potensi destinasi wisata di Indonesia, pulau Bali sudah sangat terkenal dengan pesona alam yang indah, adat istiadatnya dan juga budayanya, hal itu menyebabkan Bali banyak sekali dikunjungi oleh wisatawan domestik maupun mancanegara. Data dari Badan Pusat Statistik Provinsi Bali tahun 2018 jumlah wisatawan domestik yang berkunjung ke Bali sejumlah 9.757.991 (11.70\%) dan wisatawan mancanegara sejumlah 6.070 .473 (6.54\%) BPS (2019) dari data tersebut tentunya hal ini akan berpengaruh terhadap pendapatan masyarakat Bali khususnya. Data diatas menunjukan bahwa potensi pariwisata pulau Bali sangat tinggi, oleh karena itu tantangan tersendiri bagi pulau Bali untuk tetap menjaga kelestarian lingkungannya, agar tingkat pariwisata di Bali tetap terjaga.

Pertumbuhan ekonomi yang sangat cepat tentu mendorong terjadinya konsumsi dan ekploitasi sumber daya alam secara berlebihan sehingga mengakibatkan kerusakan lingkungan. Implikasi dari kerusakan lingkungan menurut Biswas \& Roy (2015) antara lain berupa pemanasan global, degradasi lingkungan (tanah, udara, dan air), penipisan lapisan ozon, serta berdampak pula pada menurunnya kualitas kehidupan sosial dan kesehatan. Pencemaran dan kerusakan lingkungan yang terjadi saat ini salah satunya diakibatkan dari sampah, ada berbagai jenis sampah yang dapat mencemari lingkungan, salah satunya adalah sampah plastik. Pencemaran lingkungan akibat sampah plastik semakin mengkhawatirkan apabila tidak ada usaha untuk mengatasinya. Volume dan jenis sampah menjadi masalah yang semakin meningkat sejalan dengan jumlah penduduk, tingkat aktivitas pola kehidupan tingkat sosial ekonomi, serta kemajuan teknologi yang semakin bertambah (Setyowati \& Mulansari, 2013).

Sekitar 30-40\% kerusakan lingkungan disebabkan karena konsumsi individu yang tidak berkelanjutan, tingkat dan jenis konsumsi yang tidak berkelanjutan merupakan inti dari tantangan pembangunan berkelanjutan, teknologi lingkungan, sistem produksi, kebijakan ekonomi, dan inisiatif sosial semuanya akan memainkan peran penting dalam mencapai keberlanjutan, tetapi kontribusinya akan dirusak tanpa adanya perubahan dalam pola dan perilaku konsumsi kita (Chekima et al., (2016). Dewasa ini plastik merupakan sesuatu yang sudah tidak asing lagi di telinga masyarakat, plastik hadir dalam setiap aspek kehidupan kita sehari-hari, karena sifat plastik yang menguntungkan plastik bersifat serbaguna, hemat biaya, membutuhkan lebih sedikit energi untuk diproduksi daripada bahan alternatif seperti logam atau kaca, dan dapat diproduksi untuk memiliki banyak sifat berbeda (North \& Halden (2013). Plastik digunakan dalam berbagai aplikasi, mulai dari rumah tangga dan barang-barang pribadi, pakaian dan kemasan untuk bahan bangunan dan transportasi (Santos \& Duarte, 2015).

Intensitas penggunaan plastik sebagai kemasan pangan semakin meningkat. Hal ini disebabkan oleh banyaknya keunggulan plastik dibandingkan bahan kemasan lain. Plastik jauh lebih ringan dibandingkan gelas atau logam tidak mudah pecah, bahan ini dapat dibentuk lembaran sehingga dapat dibuat kantong atau dibuat kaku sehingga bisa dibentuk sesuai desain dan ukuran yang diinginkan (Fauzi, 2013). Tingkat ketergantungan manusia terutama konsumen terhadap plastik sudah sangat tinggi saat ini, sehingga menyebabkan plastik sebagai penyebab utama polusi yang terjadi di muka bumi, polusi plastik dilaut dilingkungan pesisir menjadi masalah yang berkembang dan harus menjadi fokus utama, plastik sekali pakai menjadi masalah utama dalam pencemaran lingkungan pantai di seluruh dunia (Van et al., 2020).

Dalam mengatasi sampah plastik, perlu adanya kebijakan dan strategi yang tepat dengan adanya sinergi antara lingkungan hidup, pertumbuhan ekonomi, stabilitas sosial dengan tujuan akhir melaksanakan pembangunan berkelanjutan salah satunya yaitu melalui pendekatan kelembagaan dan juga praktisi promosi kesehatan harus meningkatkan kesadaran publik tentang akibat berbahaya dari konsumsi tinggi barang plastik sekali pakai melalui media massa. Selain itu, mereka harus meyakinkan pembuat kebijakan untuk membuat undang-undang untuk 
p-ISSN : 2599-1418

e-ISSN : 2599-1426

meningkatkan produksi barang sekali pakai yang dapat didaur ulang (Jahani, 2019).

Salah satunya yang telah dilakukan oleh pemerintah provinsi Bali, gagasan atau kebijakan pemerintah dalam menangani hal ini adalah membuat peraturan gubernur yaitu Peraturan Gubernur Bali No. 97 Tahun 2018 tentang pembatasan timbulan sampah plastik sekali pakai yang mulai dilaksanakan pada 1 Januari 2019 yang dimana diharapkan dengan peraturan ini mampu menekan timbulan sampah terutama timbulan sampah plastik sekali pakai. Peraturan Gubernur Bali No. 97 tahun 2018 adalah sebuah terobosan awal yang dilakukan pemerintah dalam upaya pengurangan sampah plastik sekali pakai di Bali, adapun tujuan dari pada peraturan gubernur ini adalah sebagai pedoman pemerintah daerah di dalam proses merumuskan kebijakan teknis di dalam bidang Pembatasan Timbulan Sampah Plastik Sekali Pakai (PSP). Hal tersebut dilakukan untuk menjaga kesucian dan keharmonisan Bali beserta isinya, kemudian menjamin pemenuhan hak atas lingkungan hidup yang memiliki kondisi baik dan sehat akibat dampak buruk adanya pengguaan PSP sesuai dengan visi Nangun Sat Kerthi Loka Bali (melalui pembangunan semesta berencana menuju Bali era baru).

Tujuan lain dari peraturan gurbernur ini yaitu memberikan jaminan keselamatan dan kesehatan dan kehidupan masyarakat dari ancaman adanya pencemaran atau kerusakan lingkungan hidup akibat dampak dari penggunaan PSP, kemudian untuk generasi muda agar nantinya tidak tergantung lagi terhadap penggunaan PSP itu sendiri, sehingga terciptanya kualitas hidup yang lebih baik hal ini juga merupakan upaya dalam meningkatkan partisipasi masyarakat untuk berperan langsung di dalam kegiatan perlindungan lingkungan hidup, adapun jenis PSP yang dilarang di dalam peraturan gubernur ini adalah berupa kantong plastik, polysterina (styrofoam) dan juga sedotan plastik. Peraturan gubernur ini

kegunaan yang sama yang didapatkan oleh konsumen tentu hal ini juga menjadikan pertimbangan utama mereka.

Penggunaan kantong plastik oleh konsumen di Kecamatan Mendoyo,
Jurnal Pendidikan Ekonomi Undiksha

Vol. 13 No. 2 (2021)

tidak hanya ditunjukan kepada pihak industri tetapi berlaku juga terhadap pelaku usaha, dan setiap orang atau individual juga dilarang menggunakan PSP. Lembaga keagamaan juga harus melaksanakan pembinaan terhadap umatnya agar tidak menggunakanan PSP dalam kegiatan keagamaan. Aturan ini menjangkau semua pihak perangkat daerah, unit pelaksana teknis daerah, instansi pemerintah lainnya, badan usaha milik daerah, badan layanan umum daerah, lembaga swasta, lembaga keagamaan, lembaga sosial desa adat/desa pakraman, masyarakat dan perorangan dilarang menggunakan PSP dalam kegiatan sehari-hari atau dalam melakukan kegiatan sosial.

Peraturan ini tentunya menerima berbagai respon dari masyarakat terutama dari pihak konsumen, salah satunya konsumen yang ada di Kecamatan Mendoyo Kabupaten Jembrana Bali, di Kecamatan Mendoyo Kabupaten Jembrana Bali sangat mudah untuk dijumpai konsumen yang masih menggunakan sampah plastik sekali pakai terutama di pasar tradisional dari observasi awal dan wawancara yang dilakukan oleh peneliti terhadap beberapa konsumen yang berada di Kecamatan Mendoyo Kabupaten Jembrana Bali, konsumen menyatakan bahwa kebijakan ini sangat baik bagi lingkungan Bali tetapi mereka sebagai konsumen memilih tetap menggunakan sampah plastik sekali pakai dikarenakan, dilihat dari segi harga plastik sekali pakai memiliki nilai yang lebih ekonomis dibandingkan dengan pengganti plastik sekali pakai lainnya seperti sedotan plastik yang diganti dengan sedotan kertas ataupun stanless mereka memilih tetap menggunakan sedotan plastik karena perbandingan harganya yang jauh berbeda, perbandingan harga sedotan plastik yang harganya Rp. 12.000 sudah mendapatkan 250 pcs sedotan plastik dibandingkan dengan sedotan kertas yang harganya Rp. 11.000 dengan hanya mendapatkan 25 pcs sedotan, dengan nilai

Kabupaten Jembrana, Bali juga masih sangat tinggi dikarenakan sangat sering sekali konsumen lupa membawa tas belanja sehingga penjual harus tetap menyediakan kantong plastik, konsumen 
merasa pelayanan penjual kurang memuaskan dikarenakan mereka harus menambah pengeluaran untuk membeli tas belanja karena konsumen (masyarakat) belum dapat menerima apabila pusat perbelanjaan modern dan pasar tradisional tidak memberikan pelayanan berupa kemasan untuk membawa barang belanjaan mereka, pemberian kemasan untuk membawa barang belanjaan merupakan bentuk pelayanan kepada konsumen, hal ini didukung dengan hasil penelitian dari Yuliana (2016) hasil penelitiannya menunjukkan jumlah konsumen yang tidak membawa tas lebih banyak yaitu sebesar 79 persen dari pada yang membawa tas saat berbelanja yaitu sebanyak 21 persen dalam penelitian ini masyarakat juga menyatakan bahwa kebijakan tersebut akan menguntungkan pihak supermarket dan makin membebani rakyat, penelitian yang dilakukan oleh Prihartini \& Ade (2017) juga mendukung hal tersebut dimana konsumen dapat menerima kebijakan pemerintah tentang pelarangan pemberian kantong plastik di pusat perbelanjaan modern, namun konsumen sebagian masih belum menerima apabila pihak ritel (pusat perbelanjaan) tidak menyediakan kemasan untuk membawa barang belanja mereka. Saat ini kantong plastik juga semakin popular di kalangan konsumen karena disediakan dengan berbagai corak yang menarik, hal ini yang memicu peningkatan konsumsi tas belanja plastik, penelitian dari Suryani (2017) mendukung hal ini dimana dalam kebijakan plastik berbayar masyarakat juga lebih memilih untuk membeli kantong plastik daripada membawa tas belanja selain itu banyak konsumen yang tidak setuju dengan adanya kebijakan plastik berbayar dikarenakan akan menambah biaya pengeluaran.

Dari latar belakang diatas maka peneliti tertarik untuk melakukan penelitian yang berjudul Persepsi Konsumen Terhadap Peraturan Gubernur Bali No.97 Tahun 2018 Tentang Pembatasan Timbulan Sampah Plastik Sekali Pakai (Studi Kasus Di Kecamatan Mendoyo, Kabupaten Jembrana, Bali).

\section{METODE}

Jenis penelitian ini yaitu menggunakan penelitian deskriptif. Penelitian deskriptif digunakan untuk mendeskripsikan persepsi konsumen di Kecamatan Mendoyo, Kabupaten Jembrana, Bali yang ditinjau dari tiga dimensi yaitu dimensi kebutuhan, harapan dan pengalaman, populasi dalam penelitian ini yaitu seluruh konsumen yang ada di Kecamatan Mendoyo, Kabupaten Jembrana Bali. Dalam penelitian ini tehnik pengambilan sampel yang digunakan adalah sampling insidental dengan jumlah sampel sebanyak 330 orang, untuk metode pengambilan data yang digunakan berupa kuisioner dan wawancara, untuk kuisioner telah dilakukan uji reliabilitas dan validitas terlebih dahulu. Tehnik analisis data yang digunakan dalam penelitian ini adalah tehnik analisis deskriptif.

\section{HASIL DAN PEMBAHASAN}

Persepsi konsumen terhadap Peraturan Gubernur Bali No.97 Tahun 2018 tentang pembatasan timbulan sampah plastik sekali pakai ditinjau dari dimensi kebutuhan, menunjukan hasil seperti pada tabel 4.1 .

Tabel 1

Hasil Analisis Data Persepsi

\begin{tabular}{lccl}
\hline \multicolumn{1}{c}{ Dimensi } & Skor & Rentang Skor & \multicolumn{1}{c}{ Kategori } \\
\hline Kebutuhan & 4.144 & $3.366-4.158$ & Sangat Setuju \\
Total & $\mathbf{4 . 1 4 4}$ & $\mathbf{3 . 3 6 6 - \mathbf { 4 . 1 5 8 }}$ & Sangat Setuju \\
\hline
\end{tabular}

Berdasarkan tabel 4.1 maka dapat dijelaskan bahwa dimensi kebutuhan memperoleh skor sebesar 4.144 yang berada pada rentang skor 3.366 - 4.158 sehingga dikategorikan sangat setuju. Hal ini berarti konsumen beranggapan bahwa penyuluhan dan juga pemberian informasi sangat diperlukan sebagai salah satu 
kebutuhan konsumen. Secara umum persepsi konsumen terhadap peraturan Gubernur Bali No. 97 Tahun 2018 tentang pembatasan timbulan sampah plastik sekali pakai ditinjau dari dimensi kebutuhan berada dalam kategori sangat setuju.
Persepsi konsumen terhadap Peraturan Gubernur Bali No.97 Tahun 2018 tentang pembatasan timbulan sampah plastik sekali pakai ditinjau dari dimensi Harapan, menunjukkan hasil seperti pada tabel 4.2.

Tabel 2

Hasil Analisis Data Persepsi Konsumen

\begin{tabular}{lccl}
\hline \multicolumn{1}{c}{ Dimensi } & Skor & Rentang Skor & Kategori \\
\hline Harapan & 16.603 & $14.586-18.018$ & Sangat Setuju \\
Total & $\mathbf{1 6 . 6 0 3}$ & $\mathbf{1 4 . 5 8 6 - \mathbf { 1 8 . 0 1 8 }}$ & Sangat Setuju \\
\hline
\end{tabular}

Berdasarkan tabel 4.2 maka dapat dijelaskan bahwa dimensi harapan memperoleh skor sebesar 16.603 yang berada pada rentang skor 14.586 - 18.018 sehingga dikategorikan sangat setuju. Hal ini berarti konsumen beranggapan bahwa peraturan ini memiliki dampak yang sangat baik bagi konsumen terutama bagi lingkungan, konsumen juga beranggapan bahwa para penjual lebih memperhatikan tingkat kesehatan konsumen, selain itu kondisi sampah terutama di pasar tradisional juga tidak terlalu menumpuk sehingga membuat situasi dan kondisi pasar terlihat lebih bersih dan nyaman. Secara umum persepsi konsumen terhadap peraturan Gubernur Bali No. 97

Tabel 3

Hasil Analisis Data Persepsi Konsumen
Tahun 2018 tentang Pembatasan Timbulan Sampah Plastik Sekali Pakai ditinjau dari dimensi harapan berada dalam kategori sangat setuju. Dalam hal ini konsumen juga mresa kecewa karena konsumen berharap pihak penjual tetap memberikan pengganti kantong plastik sebagai kemasan belanja karena hal tersebut merupakan bentuk pelayanan penjual terhadap konsumen.

Persepsi konsumen terhadap Peraturan Gubernur Bali No.97 Tahun 2018 tentang pembatasan timbulan sampah plastik sekali pakai ditinjau dari dimensi Pengalaman, menunjukkan hasil seperti pada tabel 4.3 .

\begin{tabular}{ccccc}
\multicolumn{5}{c}{ Tabel 3 } \\
\multicolumn{4}{c}{ Hasil Analisis Data Persepsi Konsumen } \\
\hline Dimensi & Skor & Rentang Skor & Kategori \\
\hline Pengalaman & 6.625 & $5.147-6.731$ & Setuju & \\
Total & 6.625 & $5.147-6.731$ & Setuju & \\
\hline
\end{tabular}

Berdasarkan dari tabel 4.3 diatas maka dapat dijelaskan bahwa dimensi pengalaman memperoleh skor 6.625 yang berada didalam rentang skor $5.147-6.731$ yang artinya berada dalam setuju. Hal ini berarti menunjukan bahwa berdasarkan pengalaman konsumen peraturan ini membuat konsumen lebih memiliki ketertarikan terhadap produk-produk ramah lingkungan dan menjadi konsumen yang sadar terhadap konsep keberlanjutan lingkungan, peraturan ini juga sangat efektif Sesuai dengan yang telah dijabarkan diatas terdapat kesesuaian dengan yang dijelaskan oleh Wilcox (2012) yang menyatakan bahwa faktor-faktor yang mempengarauhi persepsi yaitu dapat dilihat dari segi kebutuhan, untuk menanggulangi volume sampah plastik sekali pakai.

Secara umum penelitian ini menjelaskan bagaiman persepsi konsumen terhadap Peraturan Gubernur Bali No.97 Tahun 2018 tentang pembatasan timbulan sampah plastik sekali pakai, sebagian besar hasil dari penelitian ini konsumen menyatakan setuju dengan beberapa pernyataan yang telah disajikan oleh peneliti sesuai dengan apa yang dipaparkan diatas.

harapan dan juga pengalaman. Ditinjau dari dimensi kebutuhan menunjukan hasil yang positif. Dimensi kebutuhan dalam hal ini dilihat dalam indikator informasi dalam hal ini konsumen membutuhkan penyuluhan dan 
p-ISSN : 2599-1418

e-ISSN : 2599-1426

sosialisasi terkait peraturan ini dapat melalui media elektronik dan internet atau memberikan informasi lain melalui iklan layanan masyarakat di televise dengan informasi yang diperoleh tentunya akan mengedukasi konsumen terkait dengan permasalahan sampah sehingga berdampak pada peningkatan kesadaran dan partisipasi konsumen dalam implementasi peraturan ini.

Ditinjau dari dimensi harapan dalam penelitian ini mendapatkan hasil sangat positif, konsumen sangat berharap informasi terkait dengan peraturan ini mudah dijumpai, dan dengan diberlakukannya peraturan ini dapat membantu lingkungan hidup. Dari indikator senang konsumen menilai dirasa sudah baik karena dengan adanya peraturan ini konsumen merasa bahwa pihak penjual lebih memperhatikan tingkat kesehatan konsumen dan juga kondisi sampah terutama di pasar tradisional tidak terlalu menumpuk sehingga membuat lingkungan di pasar tradisional lebih nyaman dan bersih. Sedangkan untuk indikator kecewa konsumen merasa pihak penjual tidak memberikan kemasan pengganti untuk barang belanja yang dimana konsumen masih menganggap bahwa hal itu merupakan bentuk pelayanan kepada konsumen, dengan hal tersebut konsumen tentunya harus membeli tas belanja itu membuat pengeluaran tambahan bagi pihak konsumen.

Pengalaman konsumen terkait dengan diberlakukannya peraturan ini juga baik, dilihat dari indikator tingkah laku konsumen merasa bahwa diberlakukan penelitian ini membuat konsumen lebih memiliki ketertarikan terhadap produkproduk yang ramah lingkungan, ketika berbelanja kepasar tradisional dan supermarket penjual selalu menginformasikan bahwa konsumen tidak lagi mendapatkan kantong plastik sebagai kemasan barang belanjaan, apabila dilihat dari indikator ingatan sebagai konsumen lebih muda huntuk mengingat membawa tas belanja sendiri, selain itu peraturan ini memberikan pemahaman kepada konsumen untuk lebih sadar kepada konsep keberlanjutan lingkungan, peraturan ini dirasakan konsumen efektif untuk
Jurnal Pendidikan Ekonomi Undiksha

Vol. 13 No. 2 (2021)

penanggulangan sampah plastik sekali pakai

\section{SIMPULAN DAN SARAN}

Berdasarkan hasil analisis data dan pembahasan yang dipaparkan sebelumnya oleh peneliti, maka dapat ditarik kesimpulan yaitu persepsi konsumen terhadap Peraturan Gubernur Bali No.97 Tahun 2018 tentang pembatasan timbulan sampah plastik sekali pakai dilihat dari dimensi kebutuhan konsumen menyatakan sangat setuju, selanjutnya dilihat dari dimensi harapan konsumen juga menyatakan sangat setuju sedangkan dari dimensi harapan konsumen menyatakan setuju, jadi dapat disimpulkan bahwa persepsi konsumen terkait peraturan tersebut dari ketiga indikator tersebut memperoleh hasil yang positif.

Berdasarkan hasil, pembahasan dan simpulan yang telah dipaparkan oleh peneliti sebelumnya, maka peneliti mengajukan beberapa saran yaitu sebagai berikut Bagi pemerintah Provinsi Bali agar lebih memperbanyak sosialiasasi atau penyuluhan terkait dengan peraturan ini, dan juga pemerintah diharapkan untuk mampu meningkatkan dan mendukung produksi terhadap barang-barang ramah lingkungan, sehingga nantinya konsumen mudah untuk menemukan barang-barang yang ramah lingkungan dengan harga yang lebih terjangkau. Selain itu bagi peneliti lain penelitian ini disarankan lebih dikembangkan lagi, karena di dalam penelitian ini hanya meneliti persepsi konsumen, sehingga untuk peneliti selanjutnya dapat menambah objek penelitian misalnya mengukur bagaimana persepsi serta reaksi konsumen terhadap Peraturan Gubernur Bali No.97 Tahun 2018 Tentang Pembatasan Timbulan Sampah Plastik Sekali Pakai.

\section{DAFTAR PUSTAKA}

Badan Pusat Statistik Provinsi Bali. (2019). Jumlah Kunjungan Wisatawan Mancanegara dan Domestik tahun 2018. Data per Desember 2018.

Biswas, Aindrila \& Roy. (2015). Green Products: An Exploratory Study On The 
p-ISSN : 2599-1418

e-ISSN : 2599-1426

Consumer Behavior In Emerging Economies Of The East. Journal Of Cleaner Production. 87 (1).

Chekima, B., Azizi, S., Syed, W., Wafa, K. (2016). Examining Green Consumerism Motivational Drivers : Does 10 Premium Price And Demographics Matter To Green Purchasing. Journal of Cleaner Production. 112, 3436-3450.

Fauzi Akbar, Z. A. (2013). Pengaruh Waktu Simpan Film Plastik Biodegradasi dari Pati Kulit Singkong Terhadap Sifat Mekanikalnya. Jurnal Teknik Kimia USU. 2 (2). 11-15.

Jahani, Akram. Tahereh Dedari \& Mahdi Farzadkia. (2019). Iranian Experiences In Terms of Consumption Of Disposable Single- Use Plastics: Introduction To Theoretical Variables For Developing Environmental Health Promotion Efforts. Science Direct. (16)18-22.

North, Emily J \& Halden. (2013). Plastics and Environmental Health: The Road Ahead. Reviews on Environmental Health. 28 (1).

Peraturan Gubernur Provinsi Bali No. 97 Tahun 2018 Tentang Pembatasan Timbulan Sampah Plastik Sekali Paka.

Prihartini, Erni Alfisah., \& Ade Mayvita. (2017). Persepsi Dan Reaksi Konsumen Terhadap Pemberlakuan Pelarangan Penggunaan Kantong Plastik Sebagai Kemasan Pada Pusat Perbelanjaan Modern ( Studi Konsumen Di Lingkungan Uniska Mab Banjarmasin). Jurnal Ekonomi dan Manajemen. 3(1). 527-537.
Jurnal Pendidikan Ekonomi Undiksha

Vol. 13 No. 2 (2021)

Santos, T.R. and A.C. Duarte. (2015). A Critical Overview of The Analytical Approaches to The Occurrence, The Fate and the Behavior of Microplastics in the Environment. Trends in Analytical Chemistry. (65) 47-53.

Setyowati, R., \& Mulasari, S. A. (2013). Pengetahuan Dan Perilaku Ibu Rumah Tangga Dalam Pengelolaan Sampah Plastik. Kesmas: National Public Health Journal. 7(12). 562-566.

Suryani, A. S. (2017). Persepsi Masyarakat dan Analisis Willingness To Pay Terhadap Kebijakan Kantong Plastik Berbayar Studi Di Jakarta dan Bandung. Kajian. 21(4). 359-376.

Van Rensburg, Melissa L. S'phumelele L.Nkomo \& Timothy Dube. (2020). The 'Plastic Waste Era'; Social Perceptions Towards Single-Use Plastic Consumption And Impacts On The Marine Environment In Durban, South Africa. Science Direct. Volume 114

Wilcox, Lynn. (2012). Psikologi Kepribadian. Yogyakarta: IRCISoD.

Yuliana, Surroya. (2016). Kajian Terhadap Kebijakan Kantong Plastik Berbayar Berdasarkan Analisis Perilaku Konsumen. Skripsi. Institut Teknologi Sepuluh November. 